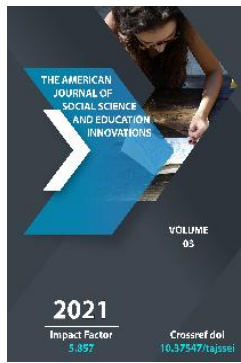

\title{
The Role And Demographic Situation Of The Southern Regions In The Economy Of Uzbekistan In 1970-1990
}

\author{
Zhovli Narzullaevich Tursunov \\ Candidate Of Historical Sciences, Associate Professor Of Faculty Of Law Civil Society, Termez State \\ University, Uzbekistan
}

Journal Website:

http://theamericanjour

nals.com/index.php/taj

ssei

Copyright: Original content from this work may be used under the terms of the creative commons attributes 4.0 licence.

\section{ABSTRACT}

This article is an interdisciplinary study that analyzes the historical demographic processes in Uzbekistan and its southern regions. Based on the archival documents first introduced into scientific circulation, the statistics reveal the problems of the demographic situation of the population as a result of the neglect of local conditions and peculiarities in Soviet policy, as well as the peculiarities of the migration process.

\section{KEYWORDS}

Geographical location, national economy, cotton ginning, light fegorose, tea weaving, demographic processes.

\section{INTRODUCTION}

One of the most important tasks facing the people of Uzbekistan in 1970-1990 was the development of industry and agriculture. The machine-building industry of Uzbekistan was transferred to the production of machinery and equipment for agriculture and irrigation. 
During these years, the task was to provide the population with food, gross industrial output, fuel, electricity, training of qualified specialists, to provide them with services in the national economy, but in this case, the geographical location and national traditions of Uzbekistan were taken into account. The program on the socio-economic life of Uzbekistan was developed by the center. Restoration and further development of cotton growing, which is the leading branch of agriculture in the country, has become the most important task for the future of the Uzbek economy, and the national economy of Uzbekistan has been united around the Cotton Industry Complex. Due to the growing attention to cotton, the number of ginneries in Surkhandarya region has increased year by year.

\section{MATERIALS AND METHODS}

In 1947, the construction of the Shurchi ginnery began, which cost $\$ 5$ million. The capital was allocated in the amount of UZS and the construction was completed in 1961. By the 1970s, 10 ginneries had been established in the province. In general, in 1946-60, many new ginneries were built in Surkhandarya, and enterprises were equipped with new machinery and technology. In Surkhandarya region, the increase in the number of ginneries had its own characteristics, and cotton growing was one of the main industries in the region. During these years, in order to develop cotton growing and agriculture in the region, the development of new lands was carried out. At the national level, agricultural production increased by $1.6 \%$ in $1950-53$, and by $7 \%$ in $1954-$ 60. In order to open new lands in the southern regions, it was necessary to build large reservoirs. Desertification was intensified mainly in 1965-75, as a result of which in 19651975 the area of cotton increased from 109 thousand hectares to 138.1 thousand hectares, grain crops from 52.1 thousand hectares to 69.1 thousand hectares, and melons from 2.6 to 4.3 hectares, or $138.5 \%$ of the total sown area. . It is also known from the dictatorial Soviet era that the recruitment of foreign labor was constant, and as a result, the supply of local labor resources with jobs became increasingly difficult.

In the late 1960s, government agencies and economic organizations tried to open branches of large enterprises, some workshops and departments in densely populated districts and overcrowded villages. As a result, 22,000 new jobs were created in several cities of Surkhandarya (Baysun, Shargun, Denov, Shurchi) in the 70s and 80 s. The development of the Surkhan-Sherabad desert and the launch of a number of enterprises have been a major factor in the socio-economic development of these cities and a number of densely populated rural areas. However, this did not mean that the region's population would be fully employed. At the time of the construction of industrial enterprises, agricultural and livestock processing enterprises in the southern regions, the number of unemployed young people, especially women, in urban and rural areas was growing. For example, in Baysun, Surkhandarya region, the construction of a large experimental tea weaving factory was started in 1966 on the basis of a small tea weaving enterprise established in 1925, and it was launched in 1972. In the same year, the factory produced products worth 907,000 soums. Also, a tweed handkerchief factory, 
built in 1971-1975, established its branches in the villages of Sariosia and Kofurun, which belong to the district. As a result, more than 600 urban and rural women have been provided with jobs and a source of income.In 1976-1980, local industrial enterprises and workshops for the production of woolen clothes and socks were built in the city, the existing old enterprises were reconstructed and equipped with new equipment and modern technologies. New equipment will be installed in agricultural machinery repair, ginning, canning and sewing factories.

As a result, the working conditions of workers have improved, first and foremost, employment. Opportunities for labor productivity have expanded, and the quality of products has improved.However, due to the irresponsibility of the administration of some enterprises in Surkhandarya and Kashkadarya regions, labor productivity and product quality have declined in some years. Similar shortcomings have had a negative impact on the steady growth of urban enterprises. For example, in 1975-79, the Surkhandarya tea factory and brick factory lost 195 hours of work due to poor safety. In 1984-85, 124 hours of working time were lost due to obsolete equipment and noninstallation of new sewing tools. It was customary in these factories not to install new looms under various pretexts. However, it should be noted that industrial enterprises, on the one hand, contributed to the development of the regional economy, on the other hand, had a negative impact on environmental degradation. This situation has had a negative impact on the health of the population living around a number of industrial enterprises in Surkhandarya. Between 1980 and 1989, the number of various diseases increased 4.8 times, the incidence of pediatric diseases 2.8 times, the incidence of adult diseases 2.2 times, the incidence of dental caries in children 2 times, and the incidence of mild fegorosis 8.8 times. During these years, the number of congenital diseases has also increased. In 1984, 700 children were born, 72 of whom suffered from congenital diseases.

In 1988, 800 children were born, 50 of whom were born with congenital diseases, and 80 were stillborn. Environmental degradation has also had a negative impact on silk production in the region. The main reason for this was the extremely simple coal mining and the launch of an aluminum plant in neighboring Tajikistan. Unfortunately, in Surkhandarya and Kashkadarya regions, as in other places in the $70 \mathrm{~s}$ and 80s, no measures were taken to protect the population from natural disasters. It should be noted that the Soviet government did not have a single organization or group that dealt with environmental issues. In the Soviet Union, it was customary to assume that everything was in order. In turn, the idea that all industrial enterprises built during this period, as well as enterprises in Surkhandarya and Kashkadarya regions, fully meet the production technology, is widely used, and the commissioned industrial buildings are considered to be environmentally friendly.

In fact, vacuum cleaners, air purifiers, and waste disposal devices installed in factories were considered to be safe, whether they were working temporarily or not at all. By the end of the 1980s, Uzbekistan's industrial relations on the scale of the former Soviet Union lagged behind the level of growth of the productive forces. The gradual increase in unresolved conflicts has hampered the 
effective use of the economic process. This discrepancy was not addressed in a timely manner, and subsequent follow-up measures were ineffective. The economic crisis has intensified. During these years, the organization of social property, economic relations, labor and wages, the mobility and variability of economic forms of economic accounting, prices, financial and credit instruments were not taken into account. As a result, it was not immediately clear that such specific forms of production relations have become obsolete and have become an obstacle to the development of production.

The Uzbek economy, which was subject to such a system of governance in the former USSR, was not designed to take into account the fundamental interests of the local population. In general, although the policy pursued by this system served to increase the economic potential of the republic, the center would have benefited more from it than from Uzbekistan. The state of the national economy of Uzbekistan on the eve of the collapse of the former Soviet Union can be exemplified by the southern regions of the republic Surkhandarya and Kashkadarya. In 1988, there were 1,623 industrial enterprises in the Republic of Uzbekistan, of which more than 92 were located in Surkhandarya and more than 100 in Kashkadarya.

In 1987, 30 industrial enterprises in southern Uzbekistan failed to meet productivity growth targets. In 1988, the volume of gross industrial output decreased even more than in 1987.In short, during the 74 years of Soviet policy, Uzbekistan became the main producer of raw materials in the country as a whole. The peaceful relocation of the economy after the Second World War, with the intervention of the center and the relocation of the productive forces without taking into account the economic and geographical potential of Uzbekistan, has expanded the cotton industry.

\section{CONCLUSION}

Many branches of the national economy of the republic were directly connected with the production or processing of cotton. As a result of the Soviet government's targeted migration policy, the indigenous population became predominantly rural. The scarcity of rural enterprises has led to a large proportion of the population engaged in productive labor being in rural areas. At the same time, the situation was serious in the southern regions of Uzbekistan, which play an important role in the national economy and agriculture. In Kashkadarya and Surkhandarya oblasts, the development of new lands and the establishment of housing did not have a positive effect on the reduction of the number of unemployed or the solution of demographic problems in general.

\section{REFERENCES}

1. Karimov IA Uzbekistan is a great country with a great future. - T .: Uzbekistan, 1992. p.62.

2. Karimov I.A Uzbekistan: national independence, economy, politics, ideology. T.1. - T .: Uzbekistan, 1996. 364 p.

3. Karimov IA We are on the path of construction and creation. - $\mathrm{T}$ : Uzbekistan, 1995. 112 p.

4. Karimov I.A May our Motherland be free and prosperous. T.2. - $\mathrm{T}$.: Uzbekistan, 1996. 382 p. 
5. Aliakberova NM, Goldfarb B.Ya., Ergashev A. Distribution of the population of the Fergana Valley (demographic aspect) - T .: Fan, 1990. - $91 \mathrm{p}$.

6. Ahmedov E. Cities of Uzbekistan. - T .: Uzbekistan, 1991. - $221 \mathrm{p}$.

7. Ahmedov E., Fayziev N. World population and the future of humanity. - $\mathrm{T}$.: Fan, 1969. 222 p,

8. Kamilova FK Demographic potential of Uzbekistan. - T .: Uzbekistan, 1991. - 143 p.

9. Allamuratov Shukhrat Ashurovich. CRAFT AND TRADE RELATIONS IN EASTERN BEKS OF THE BUKHARA EMIRATE. ACADEMICIA: An International Multidisciplinary Research Journal. Vol. 11, Issue 2, February 2021.

10. Allamuratov S.A. The role of the Amudarya waterway in cultural-religious relations of the peoples of Central Asia. //Ўтмишга назар журнали. - 2019. - Т. 24. - №. 2. pp. 23-29

11. Kushakov, S., \& Akhmedov, S. (2021). The Ethnic History And Composition Of Uzbek People: On The Example Of Two Languages, Settlement And Livestock Tribes. The American Journal of Interdisciplinary Innovations and Research, 3(02), 24-27.

12. Abdulloev, S. B. (2021). Positive Attitudes To" Dev" In Central Asian People. The American Journal of Social Science and Education Innovations, 3(01), 275-279.

13. Yusupovich, K. S. (2020). The Emergence Of Religious Views Is Exemplified By The Southern Regions. The American Journal of Social Science and Education Innovations, 2(10), 143-145.

14. Uktamovna, Y. D. (2020). The Effect Of The Russian Empire On The Political Life Of The Emirate Of Bukhara (1868-1917).
The American Journal of Social Science and Education Innovations, 2(10), 171-177

15. Orziev, Makhmud Zaynievich, and Amonkeldi Khasanovich Akhmatov. "THE CHANNEL FROM SIRDARYA TO BUKHARA: TRUTH OR FRAUD." Scientific reports of Bukhara State University 3.1 (2020): 234-239.

16. Orziev, Mahmud Zaynievich. "THE SECOND WORLD WAR AND THE UNOPENED AFGHAN FRONT." Scientific reports of Bukhara State University 4.3 (2020): 243-249.

17. Bakiev, Anvar, and Zubayda Yuldasheva. "THE FIFTH CIVILIZATION OF THE ANCIENT EAST." Theoretical \& Applied Science 8 (2020): 39-45.

18. Majidov, J. J., \& Kh, A. (2019). GLIMPSES FROM THE HISTORY OF THE AMUDARYA FLOTILLA AT THE END OF 19THBEGINNING OF THE 20TH CENTURY (on the basis of the proceedings of" Turkestan collection"). Ўтмишга назар журнали, 15(2). 